\title{
DIVERSITY OF EDAPHIC FAUNA IN DIFFERENT SOIL OCCUPATION SYSTEMS $^{1}$
}

\author{
RAIMUNDA ALVES SILVA², ALANA DAS CHAGAS FERREIRA AGUIAR ${ }^{3}$, JOSÉ MANUEL MACÁRIO REBÊLO \\ ÊNIO FARIAS DE FRANÇA E SILVA ${ }^{4}$, GERÔNIMO FERREIRA DA SILVA* ${ }^{4}$, GLÉCIO MACHADO SIQUEIRA ${ }^{2}$
}

\begin{abstract}
Soil is the habitat for a number of living organisms that perform essential functions within the ecosystem; their functions and interactions are modified according to different ways of land occupation. Thus, the objective of this study was to evaluate the diversity of edaphic fauna in different soil occupation systems. The study was carried out in different soil occupation systems: millet, maize, soybean, eucalyptus, preserved cerrado, disturbed cerrado, and pasture, with 130 pitfall traps installed per treatment. Soil fauna organisms were identified at the level of large groups (orders and family), and then examined under the following biological diversity indices: Shannon index, Pielou index, average and total richness, and abundance. The highest abundance was found under millet growing conditions (9,974 individuals), and the lowest abundance values were found in soybean soil (222 individuals) and maize ( 824 individuals). Uniform distribution of groups in the area with soybean crops, due to the homogeneous management of the area, provided the highest biological index $\left(\mathrm{H}^{\prime}=2.69\right)$. Principal component analysis (PCA) explained $50.9 \%$ of the data along the main axis and $34.6 \%$ of the data along the secondary axis. The different systems of soil occupation showed different abundance and diversity, demonstrating how soil occupation interferes with the dynamics of the invertebrate soil fauna.
\end{abstract}

Keywords: Edaphic arthropods. Soil quality. Soil invertebrates.

\section{DIVERSIDADE DA FAUNA EDÁFICA EM DIFERENTES SISTEMAS DE OCUPAÇÃO DO SOLO}

RESUMO - O solo é o habitat de vários organismos que desempenham funções essenciais para o ecossistema, cujo conjunto de funções e interações são modificadas pelas diferentes maneiras de ocupação do solo. Assim, o objetivo deste trabalho é avaliar a diversidade da fauna edáfica em diferentes sistemas de ocupação do solo. O estudo foi desenvolvido em diferentes sistemas de ocupação do solo: milheto, milho, soja, eucalipto, cerrado preservado, cerrado antropizado e pastagem, onde foram instaladas 130 armadilhas do tipo pitfall por tratamento. Os organismos da fauna do solo foram identificados a nível de grandes grupos (ordens e família), e, depois, os índices de diversidade biológica: índice de Shannon, índice de Pielou, riqueza e abundância média e total. A maior abundância foi encontrada para milheto (9.974 indivíduos), e os menores valores de abundância foram verificados para soja (222 indivíduos) e milho (824 indivíduos), respectivamente. A distribuição uniforme dos grupos na área de soja, devido ao manejo homogêneo da área, proporcionou o maior índice biológico $\left(\mathrm{H}^{\prime}=2,69\right)$. A análise de componentes principais (PCA) explicou no eixo principal 50,9\% dos dados e no eixo secundário $34,6 \%$ dos dados. Os diferentes sistemas de ocupação do solo, apresentaram abundância e diversidade distinta, demonstrando como a ocupação do solo interfere sobre a dinâmica da fauna invertebrada do solo.

Palavras-chave: Artrópodes edáficos. Qualidade do solo. Invertebrados do solo.

\footnotetext{
${ }^{*}$ Corresponding author

${ }^{1}$ Received for publication in 04/11/2018; accepted in 07/31/2019.

Paper extracted from the masters dissertation of the first author.

${ }^{2}$ Department of Geosciences, Universidade Federal do Maranhão, São Luís, MA, Brazil; ray-234@hotmail.com - ORCID: 0000-0002-0380 -8190, gleciosiqueira@hotmail.com - ORCID: 0000-0002-3513-2658.

${ }^{3}$ Department of Biology, Universidade Federal do Maranhão, São Luís, MA, Brazil; alana.aguiar@ufma.br - ORCID: 0000-0002-14394720, macariorebelo@uol.com.br - ORCID: 0000-0002-0223-0980.

${ }^{4}$ Department of Agricultural Engineering, Universidade Federal Rural de Pernambuco, Recife, PE, Brazil; effsilva@uol.com.br - ORCID: 0000-0002-8652-503X, agrogefe@yahoo.com.br - ORCID: 0000-0002-3348-7252.
} 


\section{INTRODUCTION}

The soil is a natural, vital and dynamic system which contributes uncountable functions to the ecosystems. Thus, it is important to understand the physical and chemical characteristics of soil, as well as the interactions between the organisms (BATISTA et al., 2014). Soil invertebrates play an important role in ecological processes; they are responsible for nutrient cycling (WAGG et al., 2014), energy flow (NEHER; WEICHT; BARBERCHECK, 2012), organic matter decomposition and mineralization (BERNARD; CHAPUIS-LAEDY; RAZAFIMBELO, 2012), and bioturbation that is directly associated with the formation of channels, pores, and aggregates in soil (BEDANO et al., 2016).

The epigeous faunal communities provide nutrients to plants and cause mineralogical and microstructural transformations of the soil (BERNARD;

CHAPUIS-LAEDY;

RAZAFIMBELO, 2012). However, several factors can change the soil fauna and directly interfere with the ecological services performed by them (BATISTA et al., 2014). The soil environment can be changed through soil turning, displacing the original invertebrate fauna, altering the edaphoclimatic conditions, type of soil cover, and agrochemicals used to decrease the activity of some individuals or reduce the most sensitive groups. These changes to the soil occupation have a direct influence on the communities (SIQUEIRA; SILVA; PAZ-FERREIRO, 2014) and ecology (RODRIGUES et al. 2016; SIQUEIRA et al., 2016) of edaphic fauna. Therefore, it is necessary to understand how the epigeal fauna reflects the different uses and management practices of soil (ROUSSEAU et al., 2014; MARTINS et al., 2018).

The use and management of soil are two of the factors that cause a drastic reduction in the number of fauna groups present in the soil, leading to degradation, reduction, or loss of agricultural production capacity (GORBUNOVA et al., 2017; SIQUEIRA; SILVA; PAZ-FERREIRO, 2014). The reduction or extinction of some soil invertebrate groups, and the subsequent loss of their beneficial activities, contribute to the high rates of land deterioration, fertility decline, nutrient reduction, and increase in arthropod pests (BEDANO et al., 2014). Changes in soil occupation also promote an increase in the quantity and quality of vegetal residues on soil surface. This contributes to an increase in the quantity and quality of food available to the invertebrate fauna of the soil and benefits the abundance and ecology of the epigeal fauna (BATISTA et al., 2014; MUELLER et al, 2015; BEDANO et al., 2016; FRANCO et al., 2016, RODRIGUES et al., 2016; FARIAS; HERNADEZ, 2017; al., 2017; ČUCHTA et al., 2019). However, Assis et al. (2017), Castro et al. (2018), Carvalho et al. (2018) and Čuchta et al. (2019) described that the inadequate occupation of soil and crops contributes to an imbalance in the dynamics of the taxonomic groups that compose the epigeal fauna.

Therefore, the study of invertebrate communities in the soil allows us to evaluate the functionality of these organisms in the soil and the complexity of ecological processes (FRANCO et al., 2016; WAGG et al., 2014). Additionally, we are able to assess the responses of these communities to different types of management, environmental interactions, or changes of habitat (ROUSSEAU et al., 2014). In this sense, the present study highlights the importance of abundance and diversity and utilizes the knowledge of biodiversity indicators to trace ecological functions as they respond to soil use. This study takes into account the edaphic invertebrates present in all levels of the trophic chain, and examines the dynamics of interaction which directly affect the primary production. In view of this, the biological diversity indices are parameters that consider the number of specimens collected and the distribution of the individuals within species. The values of diversity indices are indicative of the structural integrity or fragility of the community and clearly express the presence or absence of rare organisms.

An understanding of how changes in the landscape interfere with soil edaphic fauna is essential for sustainable development, since there are few studies devoted to the study of soil invertebrate fauna and their relationship with the different systems of soil occupation. Thus, the hypothesis of this study is that the composition and diversity of the edaphic fauna is altered by the occupation of the soil. The objectives of this study were: (a) to evaluate the diversity of soil fauna in different systems of soil occupation; and (b) identify taxonomic groups of soil fauna related to soil occupation.

\section{MATERIAL AND METHODS}

The study was conducted in the city of Mata Roma, in the eastern region of Maranhão State, Brazil, where the coordinates are $3^{\circ} 70^{\prime} 80.88^{\prime \prime} \mathrm{S}$ and $43^{\circ} 18^{\prime} 71.27^{\prime \prime} \mathrm{W}$. The regional climate, according to its Köppen classification, is the tropical humid type, with two well-defined seasons, one rainy (December to June) and one dry (July to November), with average annual temperatures ranging between $27^{\circ} \mathrm{C}$ and $30{ }^{\circ} \mathrm{C}$. The precipitation varies from $1,400 \mathrm{~mm}$ to $1,600 \mathrm{~mm}$, with an annual evapotranspiration of $1,144 \mathrm{~mm}^{3}$ (Figure 1).

The soil of the study area is a Xanthic Haplustox (USDA, 2010) and in the Brazilian classification it is denominated as Latossolo Amarelo Distrófico argissólico (SANTOS, 2018), whose physical and chemical characteristics in the $0-0.2 \mathrm{~m}$ layer are presented in Table 1 with a ustic regime. 


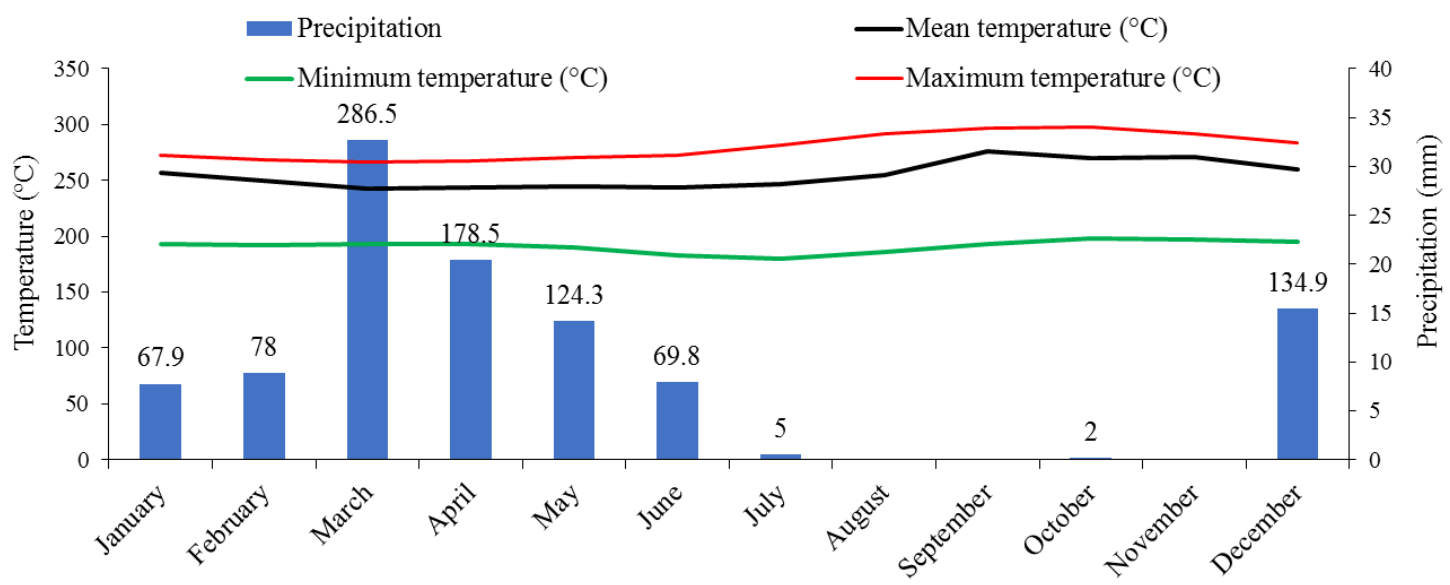

Figure 1. Average monthly temperature and precipitation in the year 2015.

The experimental plots were tested under different soil occupation systems: (1) millet (Pennisetum glaucum (L.) R. Br. - 108 ha); (2) maize (Zea mays L. - 103 ha); (3) soybean (Glycine max L. - 113 ha); (4) eucalyptus (Eucalyptus sp. - 3.79 ha); (5) preserved cerrado (33.08 ha); (6) disturbed cerrado (20.44 ha); (7) pasture [(Brachiaria brizantha (Hochst ex A. Rich.) - 3 ha)]. Pitfall traps were installed in transects containing 128 points on May 12, 2015. The use of transects to sample the soil fauna allowed for the identification of patterns of spatial variability among the samples, which is a feature not detected by random samplings. This procedure was first described by Silva et al. (2018). Due to the climate characteristics of the region (Figure 1), the month of May was chosen to collect soil fauna in the different soil occupation systems considering: a) the climatic stability (precipitation and temperature) during the growing season of summer crops and b) the fact that it is the month with the greatest differences in soil occupation within the study region.

Table 1. Granulometric characterization and chemical characterization of the soil in the studied areas.

\begin{tabular}{|c|c|c|c|c|c|c|c|}
\hline & $\begin{array}{r}\text { Clay } \\
--\end{array}$ & $\begin{array}{r}\text { Silt } \\
-\mathrm{g} \mathrm{kg}^{-1}-- \\
\end{array}$ & Sand & $\begin{array}{l}\text { Density } \\
\mathrm{Mg} \mathrm{m}^{-3} \\
\end{array}$ & $\begin{array}{l}\text { Total porosity } \\
----\mathrm{m}^{3} \mathrm{~m}^{3} \text {---- }\end{array}$ & $\begin{array}{l}\text { Microporosity } \\
---\mathrm{m}^{3} \mathrm{~m}^{3} \text {---- }\end{array}$ & $\begin{array}{l}\text { Macroporosity } \\
----\mathrm{m}^{3} \mathrm{~m}^{3}---\end{array}$ \\
\hline Millet & 120.0 & 110.0 & 490.0 & 1.56 & 32.5 & 15.2 & 22.1 \\
\hline Maize & 147.0 & 107 & 747.0 & 1.47 & 27.0 & 14.2 & 20.7 \\
\hline Soybean & 80.0 & 70.0 & 590.0 & 1.72 & 38.6 & 13.2 & 22.7 \\
\hline Eucalyptus & 257.0 & 56.0 & 657.0 & 1.32 & 30.0 & 15.9 & 20.9 \\
\hline $\begin{array}{l}\text { Preserved } \\
\text { Cerrado }\end{array}$ & 261.0 & 58.9 & 681.0 & 0.97 & 33.6 & 15.5 & 17.8 \\
\hline $\begin{array}{l}\text { Disturbed } \\
\text { Cerrado }\end{array}$ & 256.0 & 57.0 & 667.0 & 1.22 & 34.4 & 15.4 & 18.7 \\
\hline Pasture & 232.0 & 68.0 & 540.0 & 1.16 & 35.6 & 16.7 & 18.6 \\
\hline & $\begin{array}{c}\mathrm{OC} \\
\mathrm{g} \mathrm{dm}^{-3} \\
\end{array}$ & $\begin{array}{c}\mathrm{P} \\
\mathrm{mg} \mathrm{dm}^{-3}\end{array}$ & $\begin{array}{c}\mathrm{pH} \\
\mathrm{CaCl}^{2} \\
\end{array}$ & \multicolumn{4}{|c|}{------------------------ $\mathrm{mmol}_{\mathrm{c}} \mathrm{dm}^{-3}$------------------- } \\
\hline Millet & 29.0 & 18.0 & 4.6 & 2.2 & 20.0 & 4.0 & 51.2 \\
\hline Maize & 19.0 & 14.0 & 5.0 & 2.4 & 26.0 & 5.0 & 56.4 \\
\hline Soybean & 22.0 & 49.0 & 5.0 & 0.7 & 18.0 & 3.0 & 46.7 \\
\hline Eucalyptus & 27.0 & 10.0 & 4.7 & 0.3 & 14.0 & 5.0 & 54.3 \\
\hline $\begin{array}{l}\text { Preserved } \\
\text { Cerrado }\end{array}$ & 15.0 & 7.0 & 4.1 & 0.2 & 2.0 & 1.0 & 35.2 \\
\hline $\begin{array}{l}\text { Disturbed } \\
\text { Cerrado }\end{array}$ & 21.0 & 8.0 & 4.2 & 0.5 & 3.0 & 3.0 & 42.5 \\
\hline Pasture & 18.0 & 12.0 & 5.3 & 2.2 & 22.0 & 8.0 & 55.2 \\
\hline
\end{tabular}

$\mathrm{OC}=$ organic carbon; $\mathrm{P}=$ phosphorus $\mathrm{K}=$ potassium; $\mathrm{Ca}=$ calcium; $\mathrm{Mg}=$ magnesium; $\mathrm{CEC}=$ cation exchange capacity.

Soybean and maize crops were cultivated in alternate years in the experimental plots in order to conserve the soil through the no-tillage system, and millet was cultivated during the off-season to provide soil cover. Cultivation of maize, soybean, and millet began in 2007, after suppression of the original Brazilian Savannah vegetation. If compaction problems were identified in the areas of cultivation, subsoiling was conducted to a depth of $0.32 \mathrm{~m}$ every five years. Soybean cultivation was carried out with the application of foliar desiccant at the end of the crop cycle, and sampling was carried out 5 days after application of the product. The plot with eucalyptus was cultivated in 2009, with an abundant presence of 
litter. The plots with natural vegetation (preserved cerrado and disturbed cerrado) were populated by Cerrado stricto sensu or typical cerrado (Brazilian savannah). This environment is characterized by large numbers of grasses and understory trees, comprising small, twisted, and irregularly branched trees, Parkia platycephala Benth as the main species, according to IBGE (2012). The plot of disturbed cerrado is used as a natural pasture for cattle during the dry periods. The pasture area comprises a plot that was cultivated with soybean and maize between 2007 and 2014 (seven years) and later cultivated with Brachiaria brizantha (Hochst, Ex A. Rich) to provide pasture for goats and sheep.

The intensity determination of the soil use was conducted as a function of each area's historical use, with an attribution of 0 (zero) for an area with no use and a maximum value of 3 for an area with intense use (Table 2).

Table 2. Location, occupation and soil management in the areas of study.

\begin{tabular}{|c|c|c|c|c|c|}
\hline Coordinates & Occupation & Soil cover $(\%)$ & Weeds & Pesticides & $\begin{array}{l}\text { Soil use } \\
\text { intensity }\end{array}$ \\
\hline $\begin{array}{c}3^{\circ} 69^{\prime} 21.18^{\prime \prime} \mathrm{S} \\
43^{\circ} 19^{\prime} 49.3^{\prime \prime} \mathrm{W}\end{array}$ & Millet & 100 & No & Yes & 3 \\
\hline $\begin{array}{l}03^{\circ} 41^{\prime} 42.3^{\prime \prime} \mathrm{S} \\
043^{\circ} 11^{\prime} 48^{\prime \prime} \mathrm{W}\end{array}$ & Maize & 100 & No & Yes & 3 \\
\hline $\begin{array}{l}03^{\circ} 41^{\prime} 93.2 " \mathrm{~S} \\
043^{\circ} 11^{\prime} 47.5^{\prime} \mathrm{W}\end{array}$ & Soybean & 100 & No & Yes & 3 \\
\hline $\begin{array}{c}3^{\circ} 70^{\prime} 91.90^{\prime \prime} \mathrm{S} \\
43^{\circ} 18^{\prime} 86.83^{\prime} \mathrm{W}\end{array}$ & Eucalyptus & 90 & No & No & 3 \\
\hline $\begin{array}{l}03^{\circ} 41^{\prime} 90.2 " \mathrm{~S} \\
043^{\circ} 11^{\prime} 47.7^{\prime \prime} \mathrm{W}\end{array}$ & Preserved Cerrado & 100 & Yes & No & 0 \\
\hline $\begin{array}{c}3^{\circ} 71^{\prime} 09.76^{\prime \prime} \mathrm{S} \\
43^{\circ} 18^{\prime} 84.02^{\prime \prime} \mathrm{W}\end{array}$ & Disturbed Cerrado & 90 & Yes & No & 1.5 \\
\hline $\begin{array}{c}3^{\circ} 70^{\prime} 70.68^{\prime \prime} \mathrm{S} \\
43^{\circ} 18^{\prime} 13.82^{\prime \prime} \mathrm{W}\end{array}$ & Pasture & 80 & Yes & No & 3 \\
\hline
\end{tabular}

The pitfall traps were installed using plastic bottles approximately $9 \mathrm{~cm}$ tall and $8 \mathrm{~cm}$ in diameter allocated at soil level. When moving, animals would accidentally fall into the traps and remain preserved in $200 \mathrm{ml}$ of $4 \%$ formaldehyde solution contained in the bottles during the sampling period (SIQUEIRA et al., 2014). The transepts were filled with 130 traps with a spacing of $3 \mathrm{~m}$; these traps remained in the field for a period of 7 days. Thereafter, the traps were removed from the field and the contents were transferred to bottles containing $70 \%$ alcohol.

In the laboratory, the content of each bottle was transferred to a petri dish and identified by functional groups (order, family and species) with a clamp aid, a binocular magnifying glass and an identification key. In this study, the Formicidae family was separated from the Hymenoptera order due to its ecological importance in the ecosystem. After identification, all contents were returned to their respective bottles and stored in the laboratory as control material.

The following biological diversity indices were determined: Shannon Wiener Index $\left(\mathrm{H}^{\prime}\right)$, average and total richness, and Pielou equitability. The Shannon Wiener index quantifies the diversity of an area by the number of species and relative abundance and is expressed by the following formula:

$$
H^{\prime}=-\sum p_{i} \cdot \log \cdot p_{i}
$$

wherein: $H^{\prime}$ represents the diversity; pi:ni / $\mathrm{N}$ is the relative frequency of the species $I ; \mathrm{N}$ the maximum number of species. In this case, the greater the $\mathrm{H}^{\prime}$ value the greater the amount of diversity.

The Jackknife first order wealth estimator is a function of the number of species that occur in a sample, measured by observed species. The greater the number of species that occur in only one sample as compared to all samples collected in the community studied, the greater the estimate of the total number of species present in the community.

$$
E_{D}=S_{o b s}+S_{1}\left(\frac{f-1}{f}\right)
$$

The Pielou index indicates the fauna uniformity in each area. In other words, it indicates how the individuals are distributed among the different species present in the sample, and is calculated by the following equation:

$$
U=\frac{H^{\prime}}{\log _{2} S}
$$

wherein: $H^{\prime}$ represents the Shannon Wiener index, $S$ represents the group number in each area. In this case, values close to 0 indicate that some group maintains the dominance and values close to 1 indicate that the relative abundance is similar across the groups.

Nonparametric tests were applied to analyze hierarchical groupings of the taxa in the different systems of use and native areas. With the aid of the 
statistical program $\mathrm{R}$, multivariate principal components analyses (PCA) were made with the sampled areas to determine the level of relation between the variables. A grouping analysis (Cluster Analysis) was conducted using the Euclidian distance between the abundance of edaphic fauna groups as the measure of similarity for the seven areas.

\section{RESULTS AND DISCUSSION}

A total of 20,955 individuals were collected that belonged to 20 orders (Acari, Araneae, Coleoptera, Diplura, Dermaptera, Diptera, Diplopoda, Hymenoptera, Gastropoda, Isopoda, Isoptera, Lepidoptera larvae, Orthoptera, Entomobryomorpha, Psocoptera, Trichoptera, Poduromorpha, Scorpionida, Sternorrhyncha, Thysanura) and one family (Formicidae) (Figures 2 and 3).

There was a difference in the number of collected individuals. A greater number of individuals were found in the millet area $(9,974$ individuals, 14 taxa), followed by eucalyptus $(3,841$ individuals, 16 taxa), preserved cerrado $(2,384$ individuals, 15 taxa), pasture (1,933 individuals, 10 taxa), disturbed cerrado (1,777 individuals, 11 taxa), maize (824 individuals, 16 taxa) and finally soybean (222 individuals, 9 taxa) (Figure 2). The standard deviation for the number of taxa indicates that there was variation between the different soil occupations, with a larger variation in the millet area $(\mathrm{SD}= \pm$ 1,700 - Figure 2), followed by the occupation with eucalyptus ( $\mathrm{SD}= \pm 528.34$ ). These differences were expected because the area with millet showed greater abundance and dominance of a specific group (Acari - 5,772 individuals - Figure 3) and the area occupied by eucalyptus had a dominance of Poduromorpha (2,098 individuals - Figure 3), contributing to the high values of abundance and lower values of richness (Table 3). According to Martins et al. (2018), the variations in the number of individuals and taxon of the edaphic fauna is a reflection of the soil occupation system, which provides a greater or lesser contribution of biomass to the system. Studying the diversity of soil fauna in different systems of land use and occupation, Yin et al. (2019) concluded that occupation systems with a lower degree of soil disturbance affect the meso and soil macro fauna to a lesser degree. Our results corroborate those reported by Perez et al. (2013), Siqueira et al. (2016) and Silva et al. (2018), who describe soil occupation as a determinant of the diversity of soil fauna at different scales. This activity reduces, eliminates or selects for groups of organisms more or less adapted to changes in soil occupation.

Arthropods from the area with millet corresponded to $47.59 \%$ of the individuals sampled, $18.32 \%$ in the area with eucalyptus, $11.37 \%$ in preserved cerrado, $9.22 \%$, in the pasture area, $8.48 \%$ in disturbed cerrado, $3.93 \%$ in maize and $1.05 \%$ in the soybean area (Figure 3). The highest percentages of arthropods were found in the areas with millet and eucalyptus stems from the dominance of Acari and Poduromorpha (order of the Collembola group) in the sampling. A similar result was described by Yin et al. (2019) when studying fauna in different land uses, where the Acari taxonomy group and Collembola families were more abundant due to their rapid adaptation to changes in soil occupation.

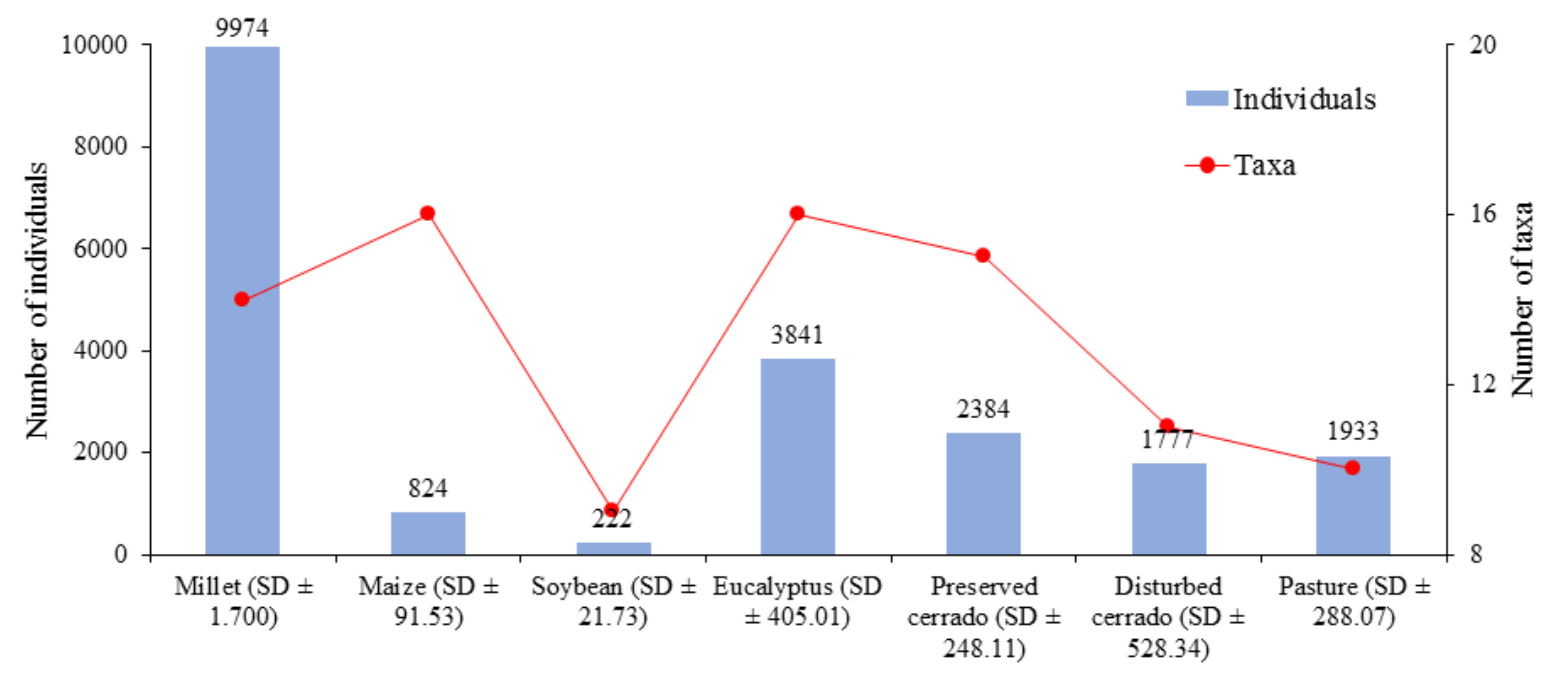

Figure 2. Number of individuals and rate per area. (Millet - 9,974 individuals), (Maize - 824 individuals), (soybean - 222 individuals), (eucalyptus - 3,841 individuals), (Preserved cerrado - 2,384 individuals), (Disturbed cerrado - 1,777 individuals) e (Pasture - 1,933 individuals) $(\mathrm{SD}=$ standard deviation). 
The most abundant groups in this study were Acari (7,706 individuals), followed by Dermaptera (3,961 individuals), Araneae (2,769 individuals) and Poduromorpha (2,159 individuals) (Figure 3). Thysanura was the group with the lowest abundance (1 individual), followed by Gastropoda (2 individuals).

The higher abundance in the area with millet (Figure 3) might have resulted from the presence of straw in the soil from previous crops; this offered food to the edaphic fauna, favoring groups such as Acari (5,772 individuals). The presence of vegetal cover or residues in the soil contributes to an increased availability of food and promotes the creation of habitats that allow a greater abundance of the population, which benefits the ecological sustainability of the production systems (BATISTA et al., 2014; BEDANO et al., 2016; FRANCO et al., 2016). The millet and pasture plots had an absence of natural enemies which combined with the high rate of female oviposition and fast hatching in Dermaptera and resulted in the higher abundance of this group in millet and pasture. The Dermaptera group is associated with the vegetal biomass input; in the millet plots, the straw left in the soil after the soybean removal contributed to its abundance. It is pertinent that Acari is a functional group of phytophagous organisms. This indicates that its abundance in agricultural areas can be explained by the quantity and quality of the biomass available in such systems (CASTRO et al., 2018). In addition, the application of agricultural inputs such as agrochemicals eliminates other functional groups that live on the soil cover and regulate the community of Acari (CARVALHO et al., 2018) that lives among the vegetal residues in the area cultivated with soybean crops. On the other hand, Poduromorpha is a heterogeneous group with contrasting life forms and adaptations to different litter strata (ČUCHTA et al., 2019). This explains the high abundance of this group in eucalyptus cultivation, because in this area the percentage of soil cover was $90 \%$ (Table 2). According to Bedano et al. (2016) soil litter quantity and quality contribute to the formation of a favorable environment for the development of soil organisms. This in turn contributes to the ecological balance and ecological complexes due to ideal conditions of humidity, aeration, temperature, $\mathrm{pH}$ and food resources in the upper layer of soil.

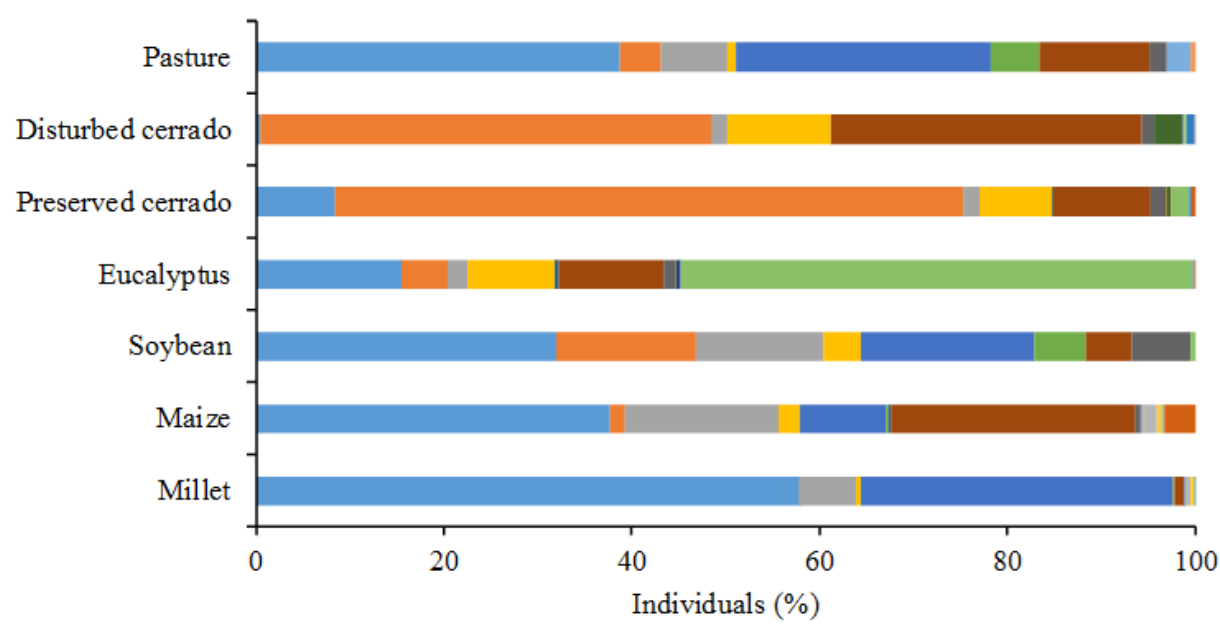

Acari

Araneae

- Coleoptera

Diplura

- Dermaptera

- Diptera

- Diplopoda

- Formicidae

- Hymenoptera

- Gastropoda

- Isopoda

- Isoptera

- Lepidoptera Larvae

= Orthoptera

- Entomobryomorpha

- Psocoptera

- Trichoptera

- Poduromorpha

- Scorpionida

- Sternorrhyncha

- Thysanura

Figure 3. Dominance and occurrence of orders and families in the study areas. (Millet, Maize, Soybean, Eucalyptus, Preserved cerrado, Disturbed cerrado and Pasture).

The abundance of edaphic faunal organisms in the experimental plots may be associated with the canopy present in each soil occupation system. According to Rodrigues et al. (2016), environmental systems in early stages have less canopy and consequently less abundance of organisms in their soil fauna. Silva et al. (2018) described that the diversity of soil fauna was influenced by the canopy, especially in areas with crops, compared to areas with eucalyptus and natural savannah-type vegetation, since the canopy is denser and closer to the ground. This structure allows for the isolation of the system with lower fluctuations in air temperature, humidity, soil water content and storage (SIQUEIRA et al., 2008).
The influence of canopy in minimizing environmental effects related to high precipitation and temperatures (SIQUEIRA et al., 2008) is reflected in the abundance of organisms and taxa (Figure 2). It is also reflected in the ecological balance between groups of organisms for each experimental plot (Figure 3). Thus, even at the high values of precipitation and temperature that occur in the region under study (Figure 1), the systems with greater canopy and less intense soil use (Table 1) are the most stable. Studying the soil fauna in sugarcane, sandbank and Atlantic forest, Siqueira et al. (2016) reported differences in the number of organisms and taxa and observed the occurrence of a higher number of taxa in the natural areas (sandbank and Atlantic 
forest) compared to the agricultural area (sugar cane). According to Kamu et al. (2017), the occurrence of natural forests in agricultural areas results in intense and rapid changes in soil, which are likely to affect the patterns of abundance and the distribution of soil fauna. This is because forest systems provide habitats and food resources to soil fauna, enabling greater activity. This finding is corroborated by (RODRIGUES et al., 2016), who found that the occurrence, abundance and diversity of beneficial organisms are all favored in diversified environments. This is especially true when favorable ecological factors exist, such as microclimatic conditions, shelter and food availability

Notably, the sampling date $(12 / 5 / 2015)$ was chosen considering the climatic characteristics of the region (Figure 1), which allowed the sampling to take place in a period with lower fluctuations in the average, minimum and maximum temperatures. The monthly precipitation in this period $(124.3 \mathrm{~mm})$ was also close to the annual average; this contributed to the understanding of how the canopy in the different systems of occupation influences the diversity of edaphic fauna. According to Siqueira et al. (2016), the diversity and abundance of edaphic fauna is influenced mainly by the values of maximum temperature and minimum temperature, since many soil organisms react or interact with the system by means of extreme thermal stimuli. They determined that the average temperature had no influence on certain taxa of the fauna of the soil.

The grouping based on the abundance of the groups showed great similarity between soybean and maize plots. this is due to the similar management adopted in both areas. The disturbed cerrado and the preserved cerrado also formed a similar grouping. Finally, cluster analysis isolated the millet area from other areas, which showed that the major food supply available was able to support a greater abundance than in other less nutrient dense areas (Figure 4).

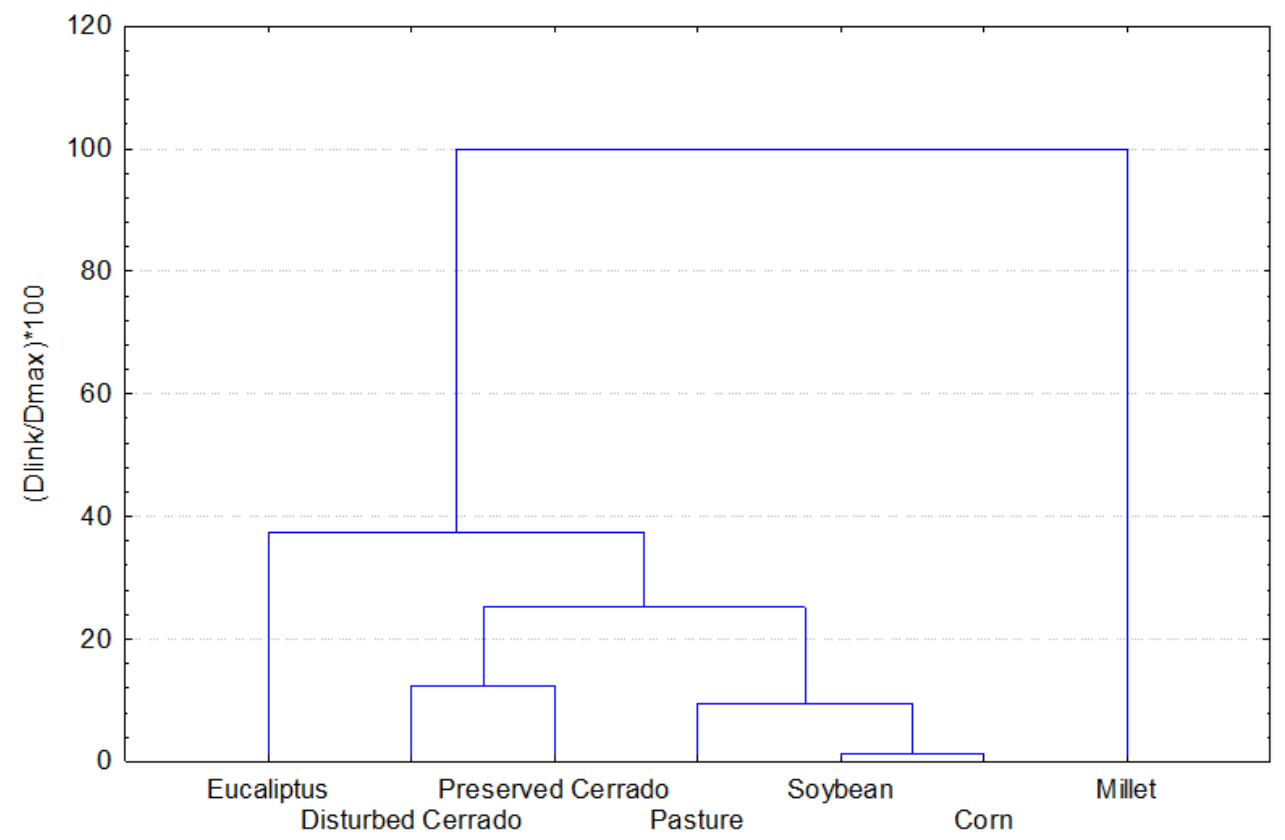

Figure 4. Dendrogram presenting the connection distance for the sampled areas (Eucalyptus, Disturbed Cerrado, Preserved Cerrado, Pasture, Soybean, Maize, and Millet).

The dissimilarity found in the area with millet is due to its higher quantity of individuals, which differentiated it from the other areas. The preserved cerrado area is a secondary forest in the regeneration process. It is possible that the short preservation time of this environment has not yet allowed greater differentiation. However, the presence of animals in the disturbed cerrado area favored the abundance of some groups, which brought the values of both areas closer. According to Baretta et al. (2006), results obtained in cluster analyses allow us to understand the differences between the soil management systems. These analyses take into account the abundance and diversity of the taxonomic groups, which are important in discerning soil preparation and cultivation systems. In addition, they are vital in understanding the dynamics of the main edaphic groups. When evaluating the biological diversity, Mueller et al. (2015) confirmed that the availability of resources is a determinant of the regulation of the edaphic invertebrate community, and that the use and management of the soil also interferes with the composition and diversity of some groups. Thus, management practices in soybean and maize agrosystems caused these areas to present similarly low abundances of individuals compared to other soil occupations. On the other hand, Paul et al. (2015) did not find soil occupation to influence the diversity of invertebrate fauna within the soil.

The abundance of individuals per $\operatorname{trap}^{-1}$ per 
day $^{-1}$ (ind.trap ${ }^{-1}$ day $^{-1}$ ) was the lowest for the soybean plots (ind.trap ${ }^{-1}$ day $^{-1}=31.71 \pm 3.10$ ), followed by maize (ind.trap ${ }^{-1}$ day $^{-1}=117.71 \pm 13.07$ ) and was greater for millet (ind.trap ${ }^{-1}$ day $^{-1}=1424.85 \pm 242.93$ ) and eucalyptus (ind.trap ${ }^{-1}$ day $^{-1}=548.71 \pm 75.47$ ) (Table 3). In this case, the application of pesticides and the absence of weeds in soybean and maize plots contributed to a lower abundance. However, the higher organic matter content in millet and eucalyptus (29 $\mathrm{g} \mathrm{dm}^{-3}$ and $27 \mathrm{~g} \mathrm{dm}^{-3}$, respectively) favored the presence of some groups, such as Coleoptera, Dermaptera and Poduromorpha.

Table 3. Ecological parameters and indexes used to evaluate the arthropod communities in the sampled areas.

\begin{tabular}{|c|c|c|c|c|c|c|}
\hline & $\begin{array}{l}\text { Abundance } \pm \text { std } \\
(\text { ind.trap } \\
\text { (1. day }\end{array}$ & CV $(\%)$ & $\begin{array}{l}\text { Shannon } \\
\text { index }\end{array}$ & $\begin{array}{l}\text { Pielou } \\
\text { index }\end{array}$ & $\begin{array}{l}\text { Average } \\
\text { richness }\end{array}$ & $\begin{array}{l}\text { Total } \\
\text { richness }\end{array}$ \\
\hline Millet & $1424.85 \pm 242.93$ & 17.04 & 1.44 & 0.37 & 3.43 & 14 \\
\hline Maize & $117.71 \pm 13.07$ & 11.10 & 2.42 & 0.60 & 2.52 & 16 \\
\hline Soybean & $31.71 \pm 3.10$ & 9.78 & 2.69 & 0.84 & 1.48 & 9 \\
\hline Eucalyptus & $548.71 \pm 75.47$ & 13.75 & 2.08 & 0.52 & 4.04 & 16 \\
\hline Preserved Cerrado & $340.57 \pm 57.85$ & 16.98 & 0.73 & 0.44 & 2.43 & 15 \\
\hline Disturbed Cerrado & $253.85 \pm 41.15$ & 16.21 & 1.85 & 0.53 & 2.80 & 11 \\
\hline Pasture & $276.14 \pm 35.44$ & 12.83 & 2.42 & 0.73 & 3.30 & 10 \\
\hline
\end{tabular}

$\mathrm{Std}=$ standard deviation; Ind. $\operatorname{trap}^{-1} \cdot$ day $^{-1}=$ individuals $\operatorname{trap}^{-1} \mathrm{day}^{-1} ; \mathrm{CV} \%=$ coefficient of variation

In the same way, a desiccant application in the soybean plantation explains the lower abundance in this area in conjunction with the constant use of the pesticide. The edaphic community is mainly influenced by the anthropic action (GORBUNOVA et al., 2017), with respect to the use and management of the soil (ASSIS et al., 2017), which directly interferes with the abundance and diversity (SANTOS et al., 2008). This is associated with the physical disturbances and the changes in the quantity and quality of the organic matter (FARIAS; HERNÁDEZ, 2017; PANT et al., 2017).

Due to the low density of ants, a natural predator of mites, the mite population shows dominance, mainly in millet. In tropical climates, the disproportionate representation of Acari can be attributed to the two well-defined seasons, a dry and a rainy one, which constitute a normal pattern for the species (BLANKINSHIP et al., 2011). According to Blankinship et al. (2011) it may also be the result of adaptation to regime variations of temperature and water.

The highest diversity (Shannon index) was recorded in soybean plots $\left(\mathrm{H}^{\prime}=2.69\right)$, followed by the maize area $\left(\mathrm{H}^{\prime}=2.42\right)$, pasture $\left(\mathrm{H}^{\prime}=2.42\right)$, eucalyptus $\left(\mathrm{H}^{\prime}=2.08\right)$, disturbed cerrado $\left(\mathrm{H}^{\prime}=\right.$ $1.85)$, millet $\left(\mathrm{H}^{\prime}=1.44\right)$ and preserved cerrado $\left(\mathrm{H}^{\prime}=\right.$ 0.73 ) (Table 3). In all the areas, the average value of Shannon diversity was superior to 1 , except for in the preserved cerrado.

The higher Shannon diversity in the area with soybean results from the presence of equally distributed groups; dominance was not observed in this area. Shannon diversity values above 1 indicate that the diversity of soil fauna is high and similar values have been reported in other studies (SIQUEIRA et al., 2014, 2016; MARTINS et al., 2018).

The species diversity is calculated through a relation between the species number and the number of individuals distributed between the species, so when the samplings present the same number of individuals the index will assume its maximum value. In practical terms, the values assumed by the Shannon index are between 1.5 and 3.5 and only rarely exceed the value of 4.5 .

The Pielou index showed a greater uniformity in the soybean areas $(U=0.84)$, pasture $(U=0.73)$ and maize $(U=0.60)$ (Table 3$)$, despite the low abundance in these areas, the individuals are found well distributed among the groups, unlike millet, for example. The highest average richness corresponded to the area with eucalyptus (average richness $=4.04$ ) and the total richness was higher in maize and eucalyptus (total richness $=16$ ), followed by the preserved cerrado (total richness $=15$ ) and millet (total richness $=14$ ). The lowest richness corresponded to the area with soybean (total richness $=9$ ). The management and the intensification of land use only affected the abundance; it did not interfere with the diversity and richness. The intensity of land use leads to a reduction in the abundance and richness of predators, interfering with the ecological functions of the soil. Often decades are needed for these environments to recover (ROUSSEAU et al., 2014).

In the Principal Component Analysis (PCA) (Figure 3 ), the main axis reported $50.9 \%$ (PCA 1) and the secondary axis reported $34.6 \%$ (PCA 2). The analysis of principal components allowed for the identification of the soil fauna taxa with higher correlation to their respective systems of soil occupation. The PCAs enabled the identification of the most differentiated occupation systems, namely: 1) eucalyptus, relating to the Isopoda, Poduromorpha, and Gastropoda taxa; 2) Preserved cerrado and disturbed cerrado, which were related to Thysanura, Araneae and Isoptera; 3) Millet with Dermaptera; and 4) Pasture, soybean and maize, which were related to the other groups of taxa with higher or lower correlations. 


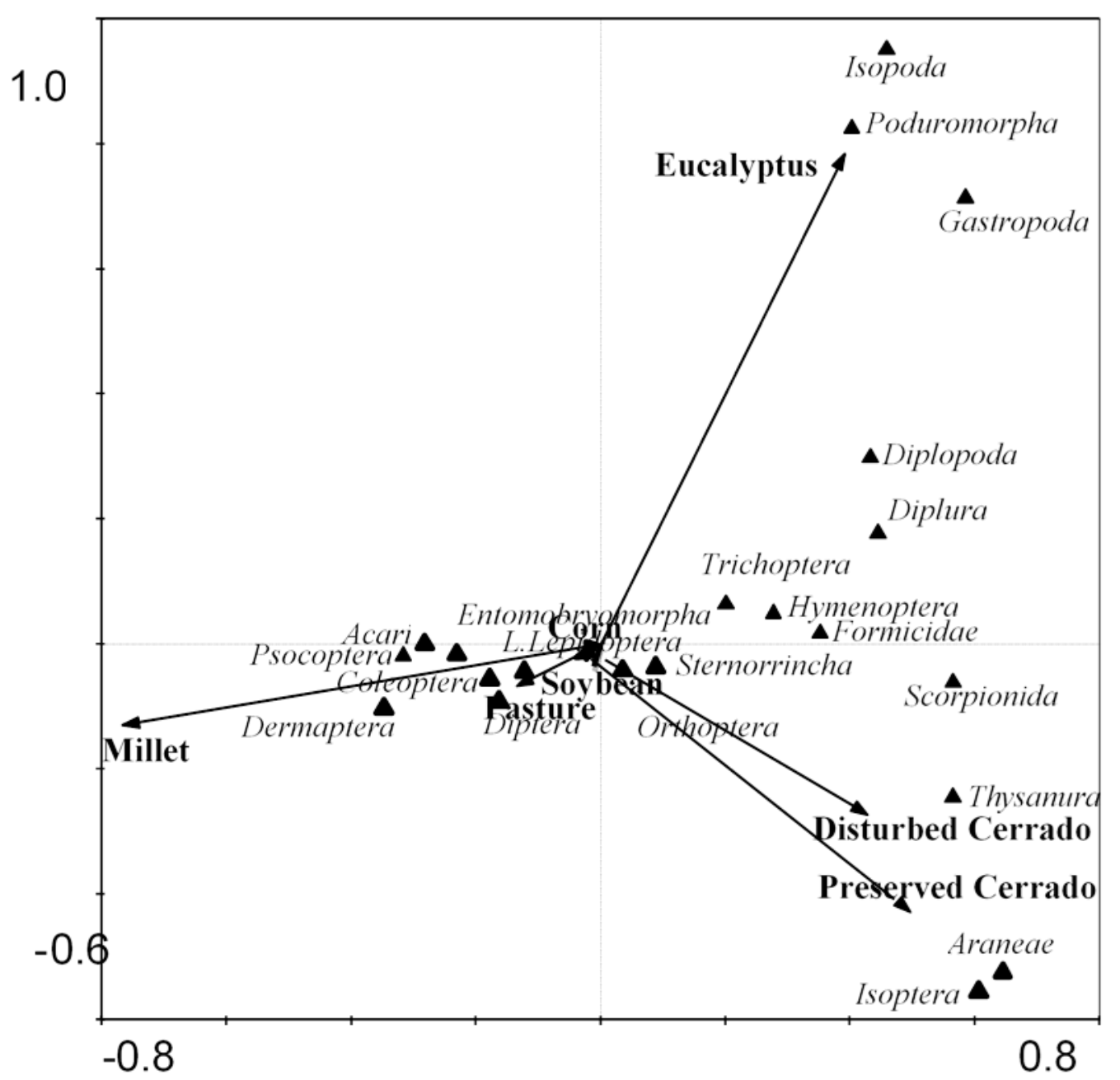

Figure 5. The principal components analysis of the relationship between groups of edaphic arthropods and the planting areas: Millet, Maize, Soybean, Eucalyptus, Preserved Cerrado, Disturbed Cerrado and pasture.

It was noted that in the soil occupation systems with eucalyptus (1), preserved cerrado and disturbed cerrado (2), the correlation with soil fauna taxa appear in the first and fourth quadrants, with eucalyptus showing a larger angle with respect to the axis of the abscissa compared to the systems occupied by natural vegetation with and without disturbance. It is also apparent that the soil fauna groups that correlate with eucalyptus (Isopoda, Poduromorpha and Gastropoda) are organisms related to environments with high content of soil organic matter, as well as with a high content of soil water and soil water storage (SIQUEIRA et al., 2016). By contrast, the organisms associated with the soil use systems with natural vegetation (preserved cerrado and disturbed cerrado) are correlated with the organisms (Thysanura, Araneae and Isoptera), which are related to different plant and soil strata. The Isoptera group is comprised of organisms which are fundamentally important for nutrient cycling and soil aeration (ROY et al., 2018).

The correlation between soil occupation with crops and the order Dermaptera is widely known (CASARIL et al., 2019), since these organisms have a preference for shaded and humid environments. These are predatory omnivores of different soil organisms, including mites which are in greater abundance in this system of soil occupation. Soil arthropods that correlate with soil occupation with pasture, soybean and maize growing have different ecological functions and relationships with agricultural systems, and the relationship is often determined by selective feeding habits due to the high content and availability of. These are considered insect pests as they cause high losses to agriculture (MARTINS et al., 2018).

\section{CONCLUSIONS}

The diversity of soil fauna was affected by soil occupation, and a great dissimilarity was found in systems with agricultural occupation (soybean, maize, and millet).

The plot cultivated with soybean crops showed the highest diversity $\left(H^{\prime}=2.69\right)$, reflecting the balanced distribution of taxonomic groups. This was 
an environmental response to the homogeneous management of the area and resulted in the highest Pielou equitability $(\mathrm{U}=0.84)$.

The highest occurrence of certain taxonomic groups (Acari (millet), Poduromorpha (Eucalyptus) and Araneae (Cerrado preserved)), confirmed that the soil occupation system interferes in the abundance of edaphic faunal organisms. This confirms that occupation systems with greater intensity of soil use contribute to the reduction in diversity and create an imbalance in the epigeal fauna along the landscape.

\section{ACKNOWLEDGEMENTS}

The authors would like to thank $\mathrm{CNPq}$ (Conselho Nacional de Desenvolvimento Cientifico e Tecnológico) and FAPEMA (Fundação de Amparo à Pesquisa e ao Desenvolvimento Científico e Tecnológico do Maranhão).

\section{REFERENCES}

ASSIS, P. C. R. et al. Biological Soil Properties in Integrated Crop-Livestock-Forest Systems. Revista Brasileira de Ciência do Solo, v. 41, s/n., p. e0160209, 2017.

BARETTA, D. et al. Efeito do cultivo do solo sobre a diversidade da fauna edáfica no planalto sul catarinense. Revista de Ciências Agroveterinárias, v. 5, n. 2, p. 108-117, 2006

BATISTA, I. et al. Frações oxidáveis do carbono orgânico total e macrofauna edáfica em Sistema de integração lavoura-pecuária. Revista Brasileira de Ciência do Solo, v. 38, n. 3, p. 797-809, 2014.

BEDANO, J. C. et al. Effect of Good Agricultural Practices under no-till on litter and soil invertebrates in areas with different soil types. Soil \& Tillage Research, v. 158, n. 1, p. 100-109, 2016.

BERNARD, L.; CHAPUIS-LAEDY, L.; RAZAFIMBELO, T. Endogeic earthworms shape bacterial functional communities and affect organic matter mineralization in a tropical soil. The ISME Journal, v. 6, n. 1, p. 222-231, 2012.

BLANKINSHIP, J. C. et al. A meta-analysis of responses of soil biota to global change. Oecologia, v. 165 , n. 3 , p. 553-565, 2011.

CASTRO, E. B. et al. Population dynamics of the main phytophagous and predatory mites associated with rubber tree plantations in the State of Bahia, Brazil. Systematic \& Applied Acarology, v. 23, n. 8 , p. $1578-1591,2018$.

CARVALHO, N. L. et al. Ácaros fitófagos em plantas cultivadas e os fatores que interferem em sua dinâmica populacional. Revista Eletronica Tecnicocientífica de IFSC, v. 2, n. 7, p. 1-17, 2018.

CASARIL, C. E. et al. Fauna edáfica em sistemas de produção de banana no Sul de Santa Catarina. Revista Brasileira de Ciências Agrárias, v. 14, n. 1, p. e5613, 2019.

ČUCHTA, P. et al. An important role of decomposing wood for soil environment with a reference to communities of springtails (Collembola). Environmental Monitoring and Assessment, v. 191, n. 4, p. 191-222, 2019.

FARIAS, P. M.; HERNÁDEZ, M. I. M. Dung Beetles Associated with Agroecosystems of Southern Brazil: Relationship with Soil Properties. Revista Brasileira de Ciência do Solo, v. 41, s/n., p. e0160248, 2017.

FRANCO, A. L. C. et al. Loss of soil (macro)fauna due to the expansion of Brazilian sugarcane acreage. Science of the Total Environment, v. 563, s/n., p. 160-168, 2016.

GORBUNOVA, A. YU. et al. Forest fires increase variability of soil macrofauna communities along a macrogeographic gradient. European Journal of Soil Biology, v. 80, s/n., p. 49-52, 2017.

INSTITUTO BRASILEIRO DE GEOGRAFIA E ESTATÍSTICA - IBGE. Manual técnico da vegetação brasileira. 2. ed. Rio de Janeiro, Diretoria de Geociências. Coordenação de Recursos Naturais e Estudos Ambientais, 2012. 271 p.

KAMU, S. et al. Soil macrofauna abundance under dominant tree species increases along a soil degradation gradient. Soil Biology and Biochemistry, v. 112, s/n., p. 35-46, 2017.

MARTINS, A. L. P. et al. Associations Between Different Soil Management Practices, Soil Fauna and Maize Yield. Journal of Agricultural Science, v. 10, n. 9, p. 333-343, 2018.

MUELLER, K. E. et al. Light, earthworms, and soil resources as predictors of diversity of 10 soil invertebrate groups across monocultures of 14 tree species. Soil Biology Biochemistry. v. 92, s/n., p. 184-198, 2015.

NEHER, D. A.; WEICHT, T. R.; BARBERCHECK, M. E. Linking invertebrate communities to decomposition rate and nitrogen availability in pine forest soils. Applied Soil Ecology, v. 54, s/n., p. 14- 
23, 2012.

PANT, M. et al. Macrofauna contributes to organic matter decomposition and soil quality in Himalayan agroecosystems, India. Applied Soil Ecology, v. 120, s/n., p. 20-29, 2017.

PAUL, B. K. et al. Exclusion of soil macrofauna did not affect soil quality but increased crop yields in a sub-humid tropical maize-based system. Agriculture, Ecosystems \& Environment, v. 208, s/n., p. 75-85, 2015.

PEREZ, G. et al. Home-field advantage: a matter of interaction between litter biochemistry and decomposer biota. Soil Biology \& Biochemistry, v. $67, \mathrm{~s} / \mathrm{n}$., p. $245-254,2013$.

RODRIGUES, D. M. et al. Diversidade de artrópodes da fauna edáfica em agroecossistemas de estabelecimento agrícola familiar na Amazônia Oriental. Revista de Ciências Agrárias, v. 59, n. 1, p. 32-38, 2016.

ROUSSEAU, G. X. et al. Macrofauna do solo em uma cronosequência de capoeiras, florestas e pastos no Centro de Endemismo Belém, Amazônia Oriental. Acta amazônica, v. 44, n. 4, p. 499-512, 2014.

ROY, S. et al. A. Soil Arthropods in Maintaining Soil Health: Thrust Areas for Sugarcane Production Systems. Sugar Tech, v. 20, n. 4, p. 376-391, 2018.

SANTOS, G. G. et al. Macrofauna edáfica associada a plantas de cobertura em plantio direto em um Latossolo Vermelho do Cerrado. Pesquisa Agropecuária Brasileira, v. 43, n. 1, p. 115-122, 2008.

SANTOS, H. G. et al. Sistema brasileiro de classificação de solos. 5. ed. Brasília, DF: Embrapa, 2018. 356 p.

SIQUEIRA, G. M.; VIEIRA, S. R.; CAMARGO, M. B. P. Variabilidade espacial do armazenamento e perda média diária de água pelo solo no sistema de semeadura direta em Campinas, SP. Bragantia, v. 67, n. 1, p. $213-223,2008$.

SIQUEIRA, G. M.; SILVA, E. F. F.; PAZFERREIRO, J. Land Use Intensification Effects in Soil Arthropod Community of an Entisol in Pernambuco State, Brazil. The Scientific World Journal, s/v., s/n., p. 1-8, 2014.
SIQUEIRA, G. M et al. Diversity of soil macrofauna under sugarcane monoculture and two different natural vegetation types. African Journal of Agricultural Research, v. 11, n. 30, p. 2669-2677, 2016.

SILVA, R. A. et al. Spatial variability of soil fauna under different land use and managements. Revista Brasileira de Ciência do Solo, v. 42, s/n., p. 1-18, 2018.

UNITED STATE DEPARTMENT OF AGRICULTURE - USDA. Soil Taxonomy: a basic system of soil classification for making and interpreting soil surveys. 2. ed. Washington: U.S. Government Printing Office, 1999. 871 p.

YIN, R. et al. Climate change does not alter land-use effects on soil fauna communities. Applied Soil Ecology, v. 140, s/n., p. 1-10, 2019.

WAGG, C. et al. Soil biodiversity and soil community composition determine ecosystem multifunctionality. Proceedings of the National Academy of Sciences of the United States of America, v. 111, n. 14, p. 5266-5270, 2016. 